\title{
The Impacts of Taxation on Capital Structure in BRICS Countries
}

\section{Rajesh Chakrabarti}

Professor, Executive Vice Dean and Director

$\underline{\text { ORCID }}$

E-mail: rajeshchakrabarti09@gmail.com

Jindal Global Business School

\section{Alexander Gruzin}

Graduate from master program "Strategic Corporate Finance"

ORCID

E-mail: gruzin.alexandr@gmail.com

NRU HSE, Moscow, Russia

Journal of Corporate Finance Research, Vol. 13, No. 3, pp. 94-110 (2019)

DOI: $10.17323 /$ j.jcfr.2073-0438.13.3.2019.94-110

Received 24 June 2019 | Peer-reviewed 10 July 2019 | Accepted 3 September 2019 


\section{The Impacts of Taxation on Capital Structure in BRICS Countries}

\section{Abstract}

Capital structure is an indicator of the value of a firm and is a key performance indicator concerning how efficiently a company operates. Debt and leverage influence a company's investment risks and influence the rate of return required by investors. Therefore, decisions affecting capital structure choice have crucial long-term effects.

The aim of this study is to determine the effects of corporate tax rates on capital structure in public nonfinancial companies based in BRICS countries. The specific object of our analysis is the evaluation of financial leverage as a proportion of debt financing based on the amount of total assets. This analysis is carried out on a sample of BRICS companies over the period from 2010 to 2015.

To conduct this research, panel data regression models are employed, including the fixed effects (FE), random effects (RE) and generalised method of moments (GMM) models. Each BRICS country is analysed separately in order to avoid biased estimates due to a host of significant country-specific differences.

The results presented herein indicate that effective tax rate is statistically significant, but the effect of taxation varies across countries. For example, effective tax rate is an important capital structure determinant, and it is significant across all countries. However in analytical terms, this investigation reveals that the most suitable regression model for the majority of BRICS countries is the fixed effects method, although for Russia the most appropriate model is the random effects method. To summarise, three separate hypotheses regarding the interplay of taxation and capital structure have This research crucially serves to demonstrate facets of the complexity of the economic situation in the key economies of BRICS countries. The generally-supported hypothesis implies that the higher the corporate tax rate, the more tax benefits the company receives from using a tax shield. The results of this study indicate that contrary to most existing literature, effective tax rate has a negative relationship with the capital structure in Russia, India and South Africa. Moreover, various existing research studies in the field have been validated, and individual aspects of our results serve to alternatively validate the tradeoff and the pecking order theories. The conclusions presented herein regarding the complexities of the interplay between economic indicators between BRICS countries will be essential information in the commercial and academic spheres and anyone concerned with emerging economies.

Keywords: financial leverage, capital structure, tax shield, effective tax rate, return on assets, depreciation, BRICS JEL classification: G21 


\section{Introduction}

Capital structure is the key topic in corporate finance. The capital structure of a company defines the value of firm, which is the key performance indicator of how good a company operates and whether it is a good idea to invest in that specific company. Thus, managers who define the leverage of a company take on a decision with long term effects, since leverage impacts on a company's investment risks and affects the rate of return required by the investors. So, the main task is to develop an optimal financial strategy that leads to the best financial results.

Since F. Modigliani and M.H. Miller published their papers $(1958,1963)[1 ; 2]$, the tradeoff theory has become one of the central theories in capital structure decision making. This theory is based upon the tax benefits of debt. It says that companies balance the benefits of debt against the costs of financial distress. Tax effects prevail at a low level of leverage, while distress costs prevail at a high level of leverage. In turn, companies have an optimal debt ratio which exactly offsets these distress costs. However, although the effects of tax on the choice of capital structure plays a central role, there are few papers that study it. These studiesestablish a solid statistical connection between capital structure choice and taxes.

The main problem is that previous research has been made using cross sectional data, and it was necessary to wait for a significant variation in tax rates to observe the tax effect on capital structure. Relations between the financial decisions of companies and tax rates attract a lot of attention, since they play a central role in capital structure theory. The main reason for this phenonemon is that the capital structure choice can change the after tax value of cash flows of the companies. Therefore, managers who are concerned about the maximising of after tax value of their firms must optimise the firms' capital structure.

Graham (2003) [3] wrote about being "not aware of any study that documents tax-related time series effects in debt usage". Graham [3] relates further that there is a gap that consists in "the lack of time series evidence about whether firm specific changes in tax status affect debt policy". The present paper meets the aforementioned Graham's conditions and tries to eliminate the gap described above by employing a panel regression with fixed and random effects.

\section{Literature review}

Capital structure is one of the key topics in corporate finance. There is a huge amount of papers written on this subject. Since this paper is focused on the impact of taxbased aspects of debt choice, I decided to make a review of most relevant theoretical and empirical works.

All modern theories of capital structure are based on a seminal work by F. Modigliani and M.H. Miller published in 1958 [1]. In their paper, the authors concluded that in perfect market conditions it does not matter what capital structure the company uses financing its operations: whether the firm finances with debt or equity, in other words there is no difference in how the company is financed (Value firm with debt $=$ Value firm without debt). The aforementioned assertions are based on the following key assumptions:

- no taxes;

- no bankruptcy costs;

- no effect of debt on a company's earnings before interest and taxes;

- $\quad$ equivalence in borrowing cost for both companies and investors;

- no transactions costs;

- $\quad$ symmetry of market information (meaning companies and investors possess the same information).

Of course, this set of assumptions is unrealistic in the real world. In Modigliani and Miller's 1963 [2] “correction article" (the first article where the tax benefit of debt was demonstrated), the assumption of a perfect market persisted, but corporate income taxation was considered. This consideration gave rise to the concept of the tax shield. According to the "classical" tax system model interest is deductible, and so it is paid before taxes.

$T S=\sum_{i=0}^{n} \frac{t \times I}{(1+r)^{i}}$

where:

TS - tax shield;

$I$ - interest;

$r$ - discount factor.

Modigliani and Miller showed that under these conditions the value of the company has a positive relation with the debt tax shield, and increases correspondingly to the debt tax shield level. The main idea of the paper proposes that the more debt a company attracts, the larger the degree of profit available to investors (equity holders and debt holders), and thus the company's value increases. Therefore, to maximise its value, the company should be financed entirely by debt. Despite the fact that the inferences of Modigliani and Miller are poorly applicable in the real world; they made a great contribution to the development of Corporate finance, in particular to the theory of capital structure.

$V_{\text {firm with debt }}=V_{\text {firm without debt }}+t_{c} D$,

where:

$V$ - company's value;

$t_{c}$ - corporate tax rate;

D - debt;

$t_{c} D$ - tax advantage of debt.

D. Dhaliwal, R. Trezevant, and Shiing-wu Wang (1992)

[4] compared the changes in companies' investment tax shields and debt tax shields before and after the (US) Recovery Act of 1981. They discovered a substitution 
effect. The authors of the research also found support for the relationship between corporate taxes and the leverage of the companies.

J.K. MacKie-Mason (1990) [5] studied the effect of taxes on corporate financing decisions. The paper clarified relationships between the tax shields and the use of debt in the studied firms. The paper showed that tax shields lower the marginal tax rate causing the firms to minimise or to have no taxable income. The obtained results support the theory that there is a positive relationship between corporate tax rates and the level of debt the firm uses to finance the operations.

D. Graham and C.R. Harvey (2001) [6] interviewed 392 chief financial executives from the US and asked them approximately 100 questions about the different indices they apply when making corporate decisions, and analysed the way these characteristics can affect the firm. Additionally, CFOs were asked about the taxation and capital structure choice, and it was found that the tax advantage of interest deductibility is a significant concern for CFOs. This finding provides some evidence that taxation is an important index in the process of defining the capital structure of firms, but the relation between taxation and capital structure depends on other characteristics such as firm size, the political and economic environment, etc.

D. Givoly and C. Hayn (1992) [7] studied the changes in corporate debt policy after the tax rates had been changed, and the effect on debt policy of the firms of the (US) Tax Reform Act of 1986. According to this act, marginal tax rates were reduced and, therefore, the use of debt by firms should be reduced. The authors found that the firms which held a high tax rate before the act was introduced, reduced their debt levels. So, this showed a positive relationship between changes in US corporate taxes and changes in corporate leverage.

J.P.H. Fan, S. Titman, and G. Twite (2012) [8] examined the interrelations between taxation, the institutional environment and capital structure. The dataset consists of nonfinancial firms from 39 developed and developing countries and it covers the period from 1991-2006. The authors found that the capital structure choice of firms is affected by the taxes in accordance with the theory, that is, when the capital gain level is positive from the use of the tax shield, the firms increase their leverage. It was also found that taxation has a positive effect on leverage in developed countries, but not in emerging economies.

R.G. Rajan and L. Zingales (1995) [9] examined the capital structure choice determinants of firms from the G-7 countries from 1987-1991. The company debt level in these countries is quite similar. It was found that those factors correlated with a firm's leverage in the US are similarly correlated in G7 countries. Also, the authors showed that taxes affect the capital structure of the firms: the use of debt is higher in countries with a higher corporate tax rate. M. Barakat and R.P. Rao (2003) [10] tested the tax models of the theory of capital structure on the data from Arab world. The authors analysed companies that belong to nonfinancial sectors of the economies. The Arab economies can be divided into 2 parts: economies that levy corporate taxes and economies that don't. This fact gives us the possibility to test the differential impact of taxes on the choice of capital structure of firms. The authors found that in those economies which impose corporate income taxes, the companies have a relatively higher leverage than those companies operating in economies that do not have a corporate tax system. It was also documented that the effective tax rate has a significant and positive impact on financial leverage. This pushes companies with higher marginal tax rates to use more debt in order to take more advantage of the tax shield debt benefit. In taxed Arab economies no evidence was found of the impact of personal taxes on capital structure choice. Barakat and Ramesh also found that debt in Arab countries is influenced by size and profitability. Their results are similar to those of Rajan and Zingales (1995) [9], who made the analysis on the data of G7 countries and Booth et al., and who analysed the data from 10 developing countries. However, the authors of this paper also made some interesting observations; for example, they found that for Arab countries the leverage value (book value) and growth are positively related. These findings are opposite to those identified for the US and other developed countries (e.g., Rajan and Zingales (1995) [9].

F.A. Longstaff and I.A. Strebulaev (2014) [11] studied the relation between corporate tax rates and leverage using an extensive historical dataset that includes data from the financial statements of US private and public companies from 1926 to 2009. The data set consists of all corporate income tax returns filed in the US during the period. The authors analysed a much longer duration for a larger sample of companies than in any prior study. The firms were divided into 3 categories: small firms - with total assets less than $\$ 10$ million, medium - with total assets between $\$ 10$ and $\$ 100$ million, and large - with total assets more than $\$ 100$ million. The authors found a strong positive relation between taxes and capital structure. An increase in corporate leverage is caused by changes in tax rates. Studying the differences with respect to firm size, they concluded that only large companies can quickly adapt corporate leverage to changes in tax rates. Medium-sized firms indicate an increase in corporate leverage with a lag, and the corporate leverage of small firms is not related to the time series variation in tax rates. These results are consistent with the presence of financial constraints with a fixed component. The fixed component causes the lag for medium companies and makes it costly for small companies to vary their leverage in response to tax incentives.

T. Bas, G. Muradoglu and K. Phylaktis (2009) [12] analysed the determinants of capital structure decisions for 25 developing countries from different regions. Their research was conducted on a dataset from the World Bank Enterprise survey. The paper focuses on small companies, since they are large contributors to the GDP of developing countries. They analysed whether the capital structure determinants differ among firms of different size, and investigated whether the capital structure determinants differ between 
private and listed firms. It was found that all firms follow the pecking order on debt financing decisions, but listed firms prefer equity financing. It was also discovered that financing decisions are not affected by internal funds, and that small and large firms follow different debt financing policies. Further results indicated that small firms have a low but growing level of debt, and as they become more diversified the risk of failure is reduced and leverage quotient can be increased. Small companies, due to asymmetry of information, have restricted access to financial resources, and therefore they have a higher interest rate cost and they are financially more risky in comparison with the large firms. These restrictions on access to finance can influence the growth of small firms. In conclusion, large listed firms have easier access to finance (international and domestic financial markets) in developing countries, but small and private firms are dependent on the state of local conditions in their countries' economies .

T. Hemmelgarn and D. Teichmann (2014) [13] analysed the influence of changes of corporate income tax rate on leverage, dividend payouts and earnings management in financial (banks) sector of the economy. A large dataset of corporate income tax reforms was selected from more than 25 countries around the world from 1997 through 2011. The results suggest that the tax changes influence all three variables: leverage, dividend payouts and earnings management, over the first 3 years after the reform was enacted. It was observed that the banks immediately reacted to corporate income tax reforms by adjusting their debt to equity ratios and dividend payouts. The income tax rate determines the value of the debt tax shield, and therefore the bank's leverage increases along with the tax rate. The higher the tax rate, the more incentives the banks have to increase debt financing, whereas the interest payments are tax deductible from the corporate income tax base. It was found that the tax effects are statistically significant. Another result was that the dividend payouts are directly related to the corporate income tax rate. This is the evidence that the banks actively use dividend payout policy as an instrument for adjusting their capital structures. Additionally, banks increase their loss loan reserves in expectation of a decline in income tax rate, because lowering the tax rate makes the losses less valuable.

A. De Socio and V. Nigro (2012) [14] studied the relationship between corporate income tax rate and leverage. Their dataset included a sample of European nonfinancial companies from 2004 to 2007. The main goal was to assess whether the debt tax shield affects decisions regarding the capital structure. In this study, they conducted a panel regression that showed a positive effect of corporate income tax on corporate leverage. The results were significant. According to the tax debt shield theory, highly profitable firms have a higher level of debt. The results are robust across different estimation methods and different proxies for the extent of financial development, and also the variations within legal systems of the countries where they are located.

J.P.H. Fan, S. Titman and G. Twite (2012) [8] examined the interrelations between taxation, institutional envi- ronment and capital structure. The dataset consists of nonfinancial firms from 39 developed and developing countries and covers the period from 1991-2006. The authors found that the capital structure choices for the firms in question are affected by the taxes in accordance with the theory: when the capital gain is positive from the use of a tax shield, firms increase their leverage. It was also found that taxation has a positive effect on leverage in developed countries, but not in emerging economies.

M.O. Nyamita, H.L. Garbharran and N. Dorasamy (2014) [15] studied the factors that influence debt financing decisions: profitability, tangibility, tax rates etc. They analysed research written by different authors and found no definite answers regarding the effect of tax rates on the capital structure of companies. However, they did discover that despite the theory that firms should increase their leverage in response to an increase of corporate tax rate (increasing the interest tax shield implies tax benefits, since debt interest payments are tax deductible), some empirical papers describe contrary results. It could appear this way because of various factors: the economic environment of a country, the size of a company etc. Nevertheless, the authors concluded that according to empirical studies there is a negative relationship between the corporate tax rate and the leverage of the firm.

S. Barrios, H. Huizinga, L. Laeven and G. Nicodème (2012) [16] provided evidence for the implications of international taxation on the organisational structure of multinational companies. They used a panel data of multinational companies from 33 European companies from 1999 to 2003 in their analyses. One of the main results made by these authors was that local tax rates have a positive impact on the financial leverage of companies.

R.H. Gordon (2010) [17] studied the impact of taxation on corporate use of debt. The dataset consisted of companies from the United States. This research found evidence for the tradeoff theory and showed that in large profitable companies the use of debt is encouraged by taxes. Companies' corporate tax liabilities fall because of interest deduction, when the companies borrow money. Thus, debt financing is subsidised by the tax law to the extent that the resulting extra taxes paid on this interest income are less than the drop in corporate tax liability.

Y. Chen and N. Gong (2011) [18] offered a new method to test the tradeoff theory (firms should increase their leverage to capture tax benefits so that the marginal tax benefits are equal to the marginal costs of debt). In this situation, the corporate tax rate rises and the companies' market value declines. As such, the firm may want to increase its leverage to increase the tax shields, although having declined market value, the company has financial constraints. Consequently, the leverage may initially increase and then decrease as the tax rate rises. There was found empirical support for the nonlinear relationship between the leverage and marginal tax rate.

T. Hartmann-Wendels, I. Stein and A. Stöter (2012) [19] in their study provided the evidence of the impact of taxes 
on capital structure choice. This study analysed a dataset that consisted of 80,173 German nonfinancial companies from 1973 to 2008 . They simulated the marginal tax rate for firms using Graham methodology. It was found that German companies are encouraged to change their capital structure, and to increase the leverage according to the deductibility allowance of interest payments in Germany. The authors showed that there is a positive and significant relationship between the leverage of the company and the marginal tax benefit of debt: an increase of marginal tax benefits of $10 \%$ causes a $1.5 \%$ increase of the debt ratio.

W. Kim and H.-J. Lee (2015) [20] studied how foreign and domestic subsidiaries and wholly-owned by individuals firms operate under Korean tax law. The difference consists in the fact that foreign subsidiaries operate under the classical tax system where double taxation of personal and corporate income provides an interest tax shield, but domestic subsidiaries are under an imputation tax system, whereby the preference of debt usage is largely eliminated. The dataset consists of non-financial wholly-owned subsidiaries (where a single major shareholder holds $100 \%$ of shares as of the end of 2010). Once the firms were selected for study, they were divided into 3 groups: foreign firms' subsidiaries, domestic firms' subsidiaries and Korean firms wholly-owned by individuals. In total, the dataset included 474 foreign subsidiaries, 684 domestic subsidiaries and 855 wholly-owned firms, (in total 2013 wholly-owned subsidiaries). Next, annual financial information for these firms from 2005-2010 was analysed. It was found that there are no significant differences in the amount of total leverage across the 3 structural categories of companies: the tax benefits don't have a first order influence on the overall leverage; and foreign subsidiaries exhibit substantially higher internal debt than domestic subsidiaries. Tax status has a first order influence on internal firms' leverage.

N. Dwenger and V. Steiner (2014) [21] studied the impact of profit taxation on the financial leverage of firms. The dataset consists of comprehensive corporate tax return data of German firms for the period 1998-2001. During this time in Germany major corporate tax reforms were introduced. A financial leverage ratio was calculated as long-term debt divided by total capital. The authors found that:

- the tax rate has a significant and relatively large positive impact on corporate leverage;

- an increase in tax rate of $1 \%$ would increase the financial leverage by $0.7 \%$;

- the debt ratio is less responsive to tax incentives for small corporations and firms that face high economic risks, due to capital market restrictions.

R. Miniaci, M.L. Parisi and P.M. Panteghini (2014) [22] analysed the relationship between subsidiary capital structure and European taxation using a tradeoff model. Their dataset includes financial data for companies from 38 European countries (extracted from the AMADEUS database). The minimal criteria for these companies were:

- more than 15 employees;

- $\quad$ operating revenue of more than 1 mln USD;
- total assets more than 2 mln USD;

- $\quad$ limited (Ltd) or Limited Liability Company (LLC).

They concluded that an increase in the foreign country tax rate raises the subsidiary leverage:

- an increase in the parent company's tax rate reduces the tax benefits of shifting debt from the parent company to its subsidiary;

- this (parent company's) tax rate increase raises the Multinational Corporation's (MNC) overall tax rate, thereby increasing the tax benefit of interest deductibility.

M. Faccio and J. Xu (2015) [23] tried to answer the following 2 questions. First, do taxes affect corporate capital structure choice? And second- how large is their economic effect? The key contribution of their paper is the use of a multitude of shifts in statutory tax rates: both at the personal and corporate level. The dataset consists of firms from 29 OECD countries during the period from 1981 to 2009 (Database: OECD Tax database, World Bank World Development indicators). The results indicate that both personal and corporate tax rates have a statistically significant relationship with the leverage, and that the impact of tax changes on capital structure appears to be economically large.

To conclude the literature review analysis, it is necessary to state that most researchers emphasise the significant effect of tax rate on the capital structure of companies.

There are some drawbacks in the analysed literature:

- there are a lot of researchers that uses cross-sectional variation in data, but Graham (2003) [3] pointed out that this effect of tax on capital structure of the firm isn't always large, and he pointed out that there is a need for research that documents tax-related time series effects in debt usage;

- many authors who analyse the impact of taxation of many countries in one research don't make a separate analysis for each country's companies. However, I consider that countries must be analysed separately, because each of the countries has its own tax legislation (corporate tax rate etc.). So, there are not considered country differences. Analysing countries together may cause biased estimates of coefficients.

In this research, initially, I analysed the impact of the effective tax rate on the leverage of each country's companies separately and then the effects were compared to each other on the country level.

On the basis of the detailed analyses of the above literature review, the following hypotheses are proposed for this study:

H1: The effective tax rate positively relates to company leverage in BRICS countries.

Most of research in the field states that the effective tax rate positively influences the leverage of the company, since the interest on debt is tax deductible. Therefore, companies attract more debt, which implies greater benefits from the tax shield. 
H2: The return on assets negatively relates to company leverage in BRICS countries.

According to the pecking order theory, more profitable companies will less use debts, and so therefore the leverage will decrease. This is supported by the paper of $\mathrm{M}$. Faccio, J. Xu (2015) [23].
H3: The inflation rate positively relates to the company leverage in BRICS countries.

According to the K. Jõeveer (2013) [43] paper, inflation has a positive relation with the leverage of the company, because in periods of high inflation rates the real value of debt's tax deductions increases.

Table 1. Description of Literature Review

\begin{tabular}{|c|c|c|c|}
\hline Name & Year & Study & Results \\
\hline Modigliani, Miller [1] & 1958 & Perfect market conditions & $\begin{array}{l}\text { It does not matter which capital structure } \\
\text { a company uses }\end{array}$ \\
\hline Modigliani, Miller [2] & 1963 & $\begin{array}{l}\text { Perfect market conditions, it was intro- } \\
\text { duced taxation }\end{array}$ & Showed the tax benefit of debt \\
\hline $\begin{array}{l}\text { DeAngelo, Masulis } \\
\text { [24] }\end{array}$ & 1980 & $\begin{array}{l}\text { The tax advantage decreases with non- } \\
\text { debt tax shields }\end{array}$ & $\begin{array}{l}\text { Firms with larger non-debt tax shields } \\
\text { have lower leverage }\end{array}$ \\
\hline Givoly, Hayn [25] & 1986 & $\begin{array}{l}\text { After the Tax Reform Act of 1986, } 10 \\
\text { years data }\end{array}$ & $\begin{array}{l}\text { Personal taxes play an important role in } \\
\text { capital structure decisions }\end{array}$ \\
\hline Scholes et al. [26] & 1990 & $\begin{array}{l}\text { Sample of firms in the commercial } \\
\text { banking industry }\end{array}$ & Positive relations between tax and leverage \\
\hline MacKie-Mason [5] & 1990 & 1,747 debt and equity issues, $1977-1987$ & $\begin{array}{l}\text { Firms with higher tax rates are more likely } \\
\text { to issue debt }\end{array}$ \\
\hline Givoly et al. [25] & 1992 & Result of the Tax Reform Act of 1986 & $\begin{array}{l}\text { Positive relation between changes in US } \\
\text { corporate taxes and leverage }\end{array}$ \\
\hline Trezevant [27] & 1992 & US companies & $\begin{array}{l}\text { Relationship between corporate taxes and } \\
\text { debt }\end{array}$ \\
\hline Rajan,Zingales [9] & 1995 & $\begin{array}{l}\text { G7, compared financial policies across } \\
\text { countries }\end{array}$ & $\begin{array}{l}\text { Use of debt is higher in countries with } \\
\text { higher corporate tax rates }\end{array}$ \\
\hline Schulman et al. [28] & 1996 & Canada, New Zealand from 1982-1991 & $\begin{array}{l}\text { Debt levels are positively correlated with } \\
\text { tax rates }\end{array}$ \\
\hline Shum [29] & 1996 & 45 countries, $1978-1989$ & $\begin{array}{l}\text { Use of debt increases under certain cir- } \\
\text { cumstances }\end{array}$ \\
\hline Cloyd et al. [30] & 1997 & US small, closely held corporations & $\begin{array}{l}\text { Taxes had a significant influence on the } \\
\text { firm's decision of using debt }\end{array}$ \\
\hline Gordon, Lee [31] & 2001 & $\begin{array}{l}\text { US statistics of income balance sheet } \\
\text { data on all corporations for } 46 \text { years } \\
\text { from } 1950-1996 \text {, to compare the debt } \\
\text { policies of firms of different sizes }\end{array}$ & $\begin{array}{l}\text { Taxes have a strong and statistically signif- } \\
\text { icant effect on debt levels }\end{array}$ \\
\hline Fan et al. [8] & 2012 & $\begin{array}{l}39 \text { countries, from 1991-2006, 36,767 } \\
\text { firms }\end{array}$ & $\begin{array}{l}\text { Taxation has a positive effect on leverage } \\
\text { in developed countries }\end{array}$ \\
\hline $\begin{array}{l}\text { Graham and Harvey } \\
{[6]}\end{array}$ & 2001 & Interview 392 CFOs in the U.S. & $\begin{array}{l}\text { Tax advantage of interest deductibility is } \\
\text { of significant concern by CFOs in large } \\
\text { companies }\end{array}$ \\
\hline
\end{tabular}


Table 2. Description of Literature review, cont'd

\begin{tabular}{|c|c|c|c|}
\hline Name & Year & Study & Results \\
\hline Ayers et al. [32] & 2001 & $\begin{array}{l}\text { Sample of small U.S. firms, }<500 \text { em- } \\
\text { ployees }\end{array}$ & $\begin{array}{l}\text { Negative relationship between the tax rate } \\
\text { and debt revealed }\end{array}$ \\
\hline Buettner et al. [33] & 2009 & $\begin{array}{l}\text { Multinationals affiliates } 26 \text { countries, } \\
1996 \text { to } 2003\end{array}$ & $\begin{array}{l}\text { Positive tax impact for both types of debt: } \\
\text { internal and external }\end{array}$ \\
\hline Dhaliwal et al. [34] & 2007 & $\begin{array}{l}\text { Effect of changes in personal tax rates, } \\
\text { the sample is divided: } 1994-1997 \text {, } \\
1997-2003,2003-2007\end{array}$ & Positive relations between tax and leverage \\
\hline Overesch, Voeller [35] & 2008 & 23 European countries, 2000 to 2005 & $\begin{array}{l}\text { Positive effect of debt tax benefit on finan- } \\
\text { cial leverage }\end{array}$ \\
\hline $\begin{array}{l}\text { Klapper, Tzioumis } \\
{[36]}\end{array}$ & 2008 & Post-2001 tax reform event in Croatia & $\begin{array}{l}\text { Positive relations between taxes and firm } \\
\text { leverage }\end{array}$ \\
\hline Jong et al. [37] & 2008 & Companies and regimes in 42 countries & No relation between taxation and debt \\
\hline Bas et al. [12] & 2009 & $\begin{array}{l}25 \text { developing countries from different } \\
\text { regions, } 27826 \text { firms }\end{array}$ & The larger the firm, the higher the leverage \\
\hline De Socio, Nigro [14] & 2012 & European companies, 2004 to 2007 & $\begin{array}{l}\text { Positive effect of corporate income tax on } \\
\text { corporate leverage }\end{array}$ \\
\hline $\begin{array}{l}\text { Hemmelgarn, Teich- } \\
\text { mann [13] }\end{array}$ & 2014 & $\begin{array}{l}\text { Banks, } 25 \text { countries around the world, } \\
1997 \text { to } 2011\end{array}$ & $\begin{array}{l}\text { Bank's leverage increases along with the } \\
\text { tax rate }\end{array}$ \\
\hline $\begin{array}{l}\text { Longstaff, Strebulaev } \\
\text { [11] }\end{array}$ & 2014 & $\begin{array}{l}\text { US private and public companies, } \\
1926-2009\end{array}$ & $\begin{array}{l}\text { Strong positive relation between taxes and } \\
\text { leverage }\end{array}$ \\
\hline
\end{tabular}

\section{Dwenger, Steiner [21] $2014 \quad$ The impact of profit taxation on the financial leverage of firms.}

Tax rate has a significant and relatively large positive impact on corporate leverage; debt ratio is less responsive to tax incentives for small corporations

An increase in the parent company's tax rate reduces the tax benefits of shifting debt from the parent company to its subsidiary
Miniaci, Parisi,Panteghini [22]
Analysed the relationship between subsidiary capital structure and European taxation using tradeoff model
Both personal and corporate tax rates have statistically significant relationship with leverage, and the economic impact of tax changes on capital structure appears to be large 
Table 3. Models used in literature review papers

$\begin{array}{llll}\text { Name } \quad \text { Year } \quad \text { Model } & \text { Results; } \\ \text { Tax rate }\end{array}$

Givoly, Hayn [25] $1992 \quad \begin{aligned} & \Delta L e v=\alpha+\beta_{1} E T R+\beta_{2} \Delta D e p+\beta_{3} \Delta I T C+\beta_{4} N O L C C+\beta_{5} D Y L D+\beta_{6} \text { Size } \\ & +\beta_{7} \text { BRisk }+\beta_{8} T B Q+\xi_{i}\end{aligned}$

Rajan,Zingales [9] $1995 \quad \Delta \operatorname{Lev}\left(\right.$ Firm $\left._{i}\right)=\alpha+\beta_{1}$ TangAssets $+\beta_{2} \frac{M V}{B V}+\beta_{3} \operatorname{Ln}($ Sales $)+\beta_{4} R O A+\xi_{i}$

$\operatorname{Lev}_{i t}=\alpha+\beta_{1} \operatorname{TInt}_{t}+\beta_{2} \operatorname{CTax}_{t}+\beta_{3} \operatorname{CTax}_{t} \operatorname{TInt}_{t}+\beta_{4}$ Size $_{i t}+\beta_{5} D S \mathrm{ec}_{i t}+\beta_{6}$ STK $_{t}$ $+\beta_{7}$ Infl $_{t}+\xi_{i t}$

Schulman et al. [28] 1996

$$
1996 \quad B_{i t}=\alpha^{\prime} W_{i t}+\beta_{1} \widehat{T}_{i t-1}^{*}+\xi_{i t}^{*}
$$

Shum [29]

Cloyd et al. [30]

$1997 I G P_{i}=\alpha+\beta_{1} I N S_{i}+\beta_{2} \operatorname{SEN}_{i} N D_{i}+\beta_{3} \operatorname{SEN}_{i} N D_{i}+\beta_{k} X_{k i}+\xi_{i}$

Gordon, Lee [31] $2001 \quad \frac{D_{s t}}{A_{s t}}=\sum_{i=0}^{7} \alpha_{i} \log \left(A_{s t}^{r}\right)^{i}+\beta\left(r_{s t}+z_{t}\left(1-r_{s t}\right)-m_{t}\right)+X_{s t^{y}}+\sum_{t \neq 1954} \delta_{t} d_{t}+\xi_{s t}$

OUTINT $_{i}=\alpha+\beta_{1} \operatorname{Tax}_{i}+\beta_{2} \operatorname{Tax}_{i}$ OCCOMP $_{i}+\beta_{3} \operatorname{Tax}_{i}$ Depr $_{i}+\beta_{4}$ Tax $_{i}$ Rent $_{i}$

Ayers et al. [32] $2001 \quad+\beta_{k} X_{k i}+\xi_{i}$

Buettner et al. [33] $2009 \quad Y_{j, k, t}=\alpha+\beta_{1} x_{j, k, t}+\beta_{2} T_{j, t}+\beta_{3} \log i_{j, t}+\beta_{k}+\beta_{t}+\xi_{j, t, k}$
Personal taxes play an important role in capital structure decisions;

Corporate tax rate

Use of debt is higher in countries with higher corporate tax rate;

Corporate tax rate

Debt levels are positively correlated to tax rates; Marginal tax rate

Use of debt increases under concrete circumstances; Corporate tax rate

Taxes had a significant influence on the firm's decision of using debt;

Corporate tax rate

Taxes have a strong and statistically significant effect on debt levels;

Corporate tax rate

Negative relationship between the tax rate and debt; Marginal tax rate

Positive tax impact for both types of debt: internal and external;

Corporate tax rate 


$\begin{array}{lll}\text { Name } \quad \text { Year } \quad \text { Model } & \text { Results; } \\ \text { Tax rate }\end{array}$

Dhaliwal et al. [34] $2007 \quad+\beta_{7}$ TRD97Inst $+\beta_{8}$ TRD03Inst $+\beta_{9} t_{c D U M}+\beta_{10}$ PPEITA $+\beta_{11}$ Tobin $Q+\beta_{12}$ PPrice $+\beta_{13}$ Size

$+\beta_{14}$ EarnVar $+\beta_{15} A A A+\beta_{16} I P O+\beta_{17}$ Proceed $+\sum_{i=1}^{7} \beta_{18 t j} I N D_{j t}$
Overesch, $\quad 2008 \quad$ Debt to Assets $_{i t}=\alpha+\beta_{11} r_{i t}^{C}+\beta_{12} r_{i t}^{D}+\beta_{13} r_{i t}^{I}+\beta_{2} X_{i t}\left(r_{i t}^{C} \times\right.$ Tang $\left._{i t}\right)$

Voeller[35] $2008+\beta_{4}\left(r_{i t}^{C} \times\right.$ LossCarryforward $\left._{i t}\right)+\delta_{i}+\gamma_{t}+\xi_{i t}$

Bas et al. [12] $2009 \quad \operatorname{Lev}_{i t}=\alpha+\beta_{1}$ Tang $_{i t}+\beta_{2}$ Prof $_{i t}+\beta_{3 A}$ Small $_{i}+\beta_{4} \frac{\text { GDP }}{\text { Cap }_{t}}+\beta_{5}$ Growth $_{t}+\beta_{6}$ Inf $_{t}$

$+\beta_{7}$ Interest $_{t}+\beta_{8}$ Tax $_{t}+\xi_{i t}$

Barakat, Rao [10] $2012 \quad \frac{D}{E}=\alpha+\beta_{1} M T R D t a x+\beta_{2} N D T S+\beta_{3} M B+\beta_{4} D i v N I+\beta_{5} T A N T A+\beta_{6} L N S$

$+\beta_{7} S D O E+\beta_{8} E B I T T A+\xi$
Tax rate

Positive relations between tax and leverage;

Corporate tax rate

Positive effect of debt tax benefit on financial lever-

age;

Effective tax rate

The larger the firm, the higher the leverage;

Corporate tax rate
Significant and positive impact on financial leverage;

Marginal tax rate
$\Delta\left(\right.$ Capital Structure $_{i t}=\alpha+\Delta$ Tax rate $_{c t-1}+\Delta$ Tax rate $_{c t-2}+\Delta$ Tax rate $_{c t-3}+\Delta$ Tax rate $_{c t-4}$

Hemmelgarn,

Teichmann [13]

2014

$+\Delta(\log (T A))^{2}{ }_{i t}+\Delta$ PretaxROA $_{i t}+\Delta \log (G D P)_{c t}+\Delta C P I_{c t}+\Delta(\min \text { CapRequirement })_{c t}+$

$+\Delta\left(\right.$ CapStrungencyIndex $_{c t}+\Delta\left({\text { Existance of DepositInsurance })_{c t}}\right.$

$+\Delta(\text { GovEffectivenessIndex })_{c t}+\delta_{j}+\gamma_{t}+\xi_{i t}$
Bank's leverage increases along with the tax rate;

Corporate tax rate

\footnotetext{
Longstaff, Strebulaev [11]

$\Delta$ Lev $_{t}=\alpha+\sum_{i=1}^{2} \beta_{i} \Delta$ Lev $_{t-1}+\sum_{i=1}^{3} \gamma_{t} \Delta$ Tax $_{\text {Rate }} t-1+\delta_{1} \Delta$ CashRatio $_{t-1}+\delta_{2} \Delta$ CurrentRatio $_{t-1}$

$+\delta_{2} \Delta$ CurrentRatio $_{t-1}+\delta_{3}$ Prof $_{t-1}+\xi_{t}$
}

Strong positive relation between taxes and leverage; Corporate tax rate 
The authors, in their various research papers, used the following tax rate models in their analyses:

Corporate tax rate: a tax paid by the firm on its earnings; there are different tax rates for different profit levels.

Marginal tax rate: tax that the firm pays on its additional dollar of income; it can increase as income increases.

Effective tax rate: an average tax rate that the firm pays; It can be calculated by dividing income tax expenses by pretax income.

\section{Data and Methodology}

The present research studies the relationships between leverage and the effective tax rate. This paper studies the influence of tax rates on companies' capital structure in each of BRICS countries and determines their statistical effect.

The dataset consists of firm level data for public companies from BRICS countries from different industries (except the financial sector) between 2010 and 2014. Company financial data were retrieved from the Bloomberg database. All the data is presented in millions of US dollars. Recently, according to official data, China, Brazil, and India started a process of transition from National Accounting Standards to International Financial Reporting Standards (IFRS). Since the companies from each country will be analysed separately (between countries) and since the national standards of these countries are very close to IFRS, it is assumed below that it is possible to conduct the regressions separately for each country's companies and then to compare results. This will indicate the influence of the effective tax rate on the capital structure. Although most determinants are the same, each country has its own model, since some variables are significant in certain countries and not in others.

This research uses the fixed effects model in order to estimate the regressions. Then, using the panel regressions method with fixed effects, it is possible to provide evidence that a change in tax rates affects a company's capital structure.

However, for the purposes of this research the corporate tax rate has been swapped in favour of the effective tax rate, since in BRICS countries there are no marginal tax rates provided by their national GAAPs.

Effective tax rate. This indicator should positively affect the leverage of the company, due to the fact that interest payments are tax deductible, i.e. a higher tax rate implies greater tax shield benefits, therefore there is a positive relation between tax rate and leverage. I. Ivashkovskaya and M. Solntseva (2007) [38], in their research on Russian data, obtained results that support negative a relation between tax rate and leverage.

Return on assets. This is calculated as the net income value divided by the total assets value. According to the tradeoff theory, more profitable companies will use debt to take greater advantage of increasing tax shields benefits. However, the pecking order theory states that more profitable companies will less use debt and therefore the leverage will decrease.

Size. This is an important determinant that impacts the capital structure of the company. It is calculated as a natural logarithm of total assets. Most papers state that the size of a company has a positive relation with the debt financing level, because large companies have a lower risk of bankruptcy, according to E.K. Kayo and H. Kimura (2011) [39]. Also, according to S. Byoun (2008) [40] large companies have lower agency costs, easier access to credit markets, and less volatile cash flows. However, I. Ivashkovskaya and M. Solntseva (2007) [41] in their investigation into data on Russian companies, identified a negative relation between debt level and the size of the firm. This fact can be explained with high agency costs and with asymmetry of information.

Depreciation/Sales. This factor is a non-debt tax shield and it has a positive relation with the leverage of the company, according to M. Faccio, J. Xu (2015) [23] and I. Ivashkovskaya, M. Solntseva (2007) [38]. This indicator may also have a negative relation with debt level.

Tangibility. This is calculated as tangible assets divided by total assets. According to the pecking order theory, tangibility is negatively related to leverage, however tradeoff theory supports a positive relation between them (Baltaci and Ayaydin, (2014) [42]).

Inflation rate. This is an important macroeconomic indicator. According to K. Jõeveer (2013) [43] and M. Faccio, J. Xu (2015) [23], it is positively related to debt level, since the real value of a debt's tax deductions becomes higher.

Profitability - This variable is calculated as earnings before interest and tax divided by revenue. According to the pecking order theory profitability has a negative relation with the company's debt level.

LIBOR. This acronym stands for London Interbank Offered Rates.

GDP increment. This value is calculated as a natural logarithm of GDP in period $t$ divided by GDP in period $t-1$.

Growth rate. This is a macroeconomic indicator that can have either a positive or negative relation with the level of debt. According to tradeoff and pecking order theories, it has a negative effect on leverage. For example, Huang and Song (2006) [44] found that growth is negatively related with the leverage. 
Table 4. Impact of the determinants on capital structure

\begin{tabular}{|c|c|c|c|c|}
\hline Variable & Decipher & Description & Impact on leverage & Author \\
\hline \multicolumn{5}{|c|}{ Dependent variable } \\
\hline $\begin{array}{l}\text { Total debt to Total } \\
\text { assets }\end{array}$ & $\mathrm{D} / \mathrm{A}$ & Financial leverage & & \\
\hline \multicolumn{5}{|c|}{ Independent variables } \\
\hline Effective tax rate & $\begin{array}{l}\text { Effective tax } \\
\text { rate }\end{array}$ & Calculated as income tax divided by pre-tax income & Positive/Negative & $\begin{array}{l}\text { Positive: Graham (2003) [3] } \\
\text { Negative: Ivashkovskaya, Solntseva (2007) [38] }\end{array}$ \\
\hline Return on assets & $\mathrm{ROA}$ & $\begin{array}{l}\text { Calculated as net income divided by total assets. Positive } \\
\text { relation: tradeoff theory; Negative: pecking order theory }\end{array}$ & Positive/Negative & Negative: Faccio, Xu (2015) [23] \\
\hline Size & Size & $\begin{array}{l}\text { Calculated as a natural logarithm of total assets. Positive } \\
\text { relation is suggested by tradeoff theory }\end{array}$ & Positive/Negative & $\begin{array}{l}\text { Kayo and Kimura (2011) [39]; } \\
\text { Ivashkovskaya, Solntseva (2007) [38] }\end{array}$ \\
\hline Depreciation/ Sales & $\begin{array}{l}\text { Depreciation/ } \\
\text { Sales }\end{array}$ & Calculated as depreciation divided by sales & Positive/Negative & $\begin{array}{l}\text { Positive: Faccio, Xu (2015) [23]; Ivashkovskaya, } \\
\text { Solntseva (2007)[38] }\end{array}$ \\
\hline Tangibility & Tangibility & Calculated as tangible assets divided by total assets & Positive/Negative & $\begin{array}{l}\text { Positive: Byoun (2008) [40]; Kayo and Kimura } \\
(2011) \text { [39]; Ivashkovskaya, Solntseva (2007) [38] }\end{array}$ \\
\hline Inflation rate & Inflation & Inflation rate & Positive & Jõeveer (2013) [43];Faccio, Xu (2015) [23] \\
\hline $\mathrm{Ni} /$ Revenue & $\mathrm{Ni} /$ Revenue & Net income margin & Positive & \\
\hline Profitability & Profitability & $\begin{array}{l}\text { Calculated as earnings before interest and tax divided by } \\
\text { revenue }\end{array}$ & Negative & Ivashkovskaya, Solntseva (2007) [38] \\
\hline LIBOR & LIBOR & London Interbank Offered Rates & Positive & \\
\hline GDP increment & $\ln \left(\frac{\mathrm{GDP}_{\mathrm{t}}}{\mathrm{GDP}_{\mathrm{t}-1}}\right)$ & $\begin{array}{l}\text { Calculated as a natural logarithm of GDP in period } t \\
\text { divided by GDP in period } t-1\end{array}$ & Negative & Faccio, $\mathrm{Xu}(2015)[23]$ \\
\hline Growth rate & Growth rate & $\begin{array}{l}\text { Calculated as capital expenditure divided by total assets. } \\
\text { According to the tradeoff and pecking order theories it has } \\
\text { a negative effect on leverage. }\end{array}$ & Negative & Brierley and Bunn (2005) [45] \\
\hline
\end{tabular}




\section{Evaluation and Estimation}

In this chapter I conduct detailed regression analyses for each of the BRICS countries and present results. Each country's data was analysed separately using panel regressions with fixed effects and random effects. The algorithm for the analysis was identical for each country's panel data. The analysis of panel data involved estimation of three types of regression: pooled, fixed effects and random effects. On the first step, using the F-test, I determined whether the pooled OLS or the fixed effects model is more suitable. Then, using Breusch-Pagan test, I determined whether the pooled OLS or random effects regression is more suitable. Additionally, a Hausman test was used to justify the use of the FE (fixed effect) or RE (random effects) model. Next, the option "vce(robust)" was added to control the model for heteroskedasticity. Thus, the most suitable model with robust results was obtained - a fixed effects model for Brazil, India, China and South Africa, but with a random effects model as the most suitable model for Russia.

The results for each country (final model variable coefficients with levels of significance) are presented in tables in their sections: Brazil, Russia, India, China and South Africa. It should be noticed that the results for each country have been obtained after the elimination of all insignificant variables from the respective regressions.

\section{Russia}

The sample consists of 340 firm-year observations for Russian companies from 2010 to 2014 (5 years). A panel regression model with random effects was utilized. The coefficient of determination of the model (i.e. R-sq) is equal to 0.23 .

The final model appears thusly:

Leverage $_{i t}$ or $\left(\frac{D}{A}\right)_{i t}=$

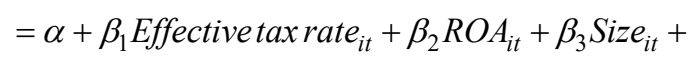

$+\beta_{4}$ Growth $_{i t}+\beta_{5}$ GDP increment ${ }_{i t}+\beta_{6}\left(\frac{E B I T}{E B T}\right)_{i t}+\xi_{i t}$

Table 5. Panel regression results for Russian companies, with random effects model

\begin{tabular}{|c|c|}
\hline Variable & Total debt/Total assets \\
\hline Effective tax rate & $\begin{array}{l}-4.55^{\star} \\
(3.23) \\
\text { p-value: } 0.15\end{array}$ \\
\hline Growth & $\begin{array}{l}2.80 \\
(3.7)\end{array}$ \\
\hline Size & $\begin{array}{l}-0.05 \\
(-0.05)\end{array}$ \\
\hline
\end{tabular}

$\begin{array}{ll}0.26^{* \star} & (0.14) \\ \text { EBIT/EBT } & -18.1^{\star \star \star \star} \\ (5.39) & \\ \text { GDP increment } & -30.6^{\star \star \star \star} \\ \text { ROA } & (7.79) \\ \text { Observations } & 340 \\ \text { R-sq within } & 0.23\end{array}$

Levels of significance: $1 \%^{\star \star \star \star}, 5 \%^{\star \star \star}, 10 \%^{\star \star}, 15 \%^{\star}$.

\section{Brazil}

The sample is comprised of 910 firm-year observations for Brazilian companies from 2010 to 2014 (5 years). A panel regression model with fixed effects was utilised. The coefficient of determination of the model (i.e. R-sq) is equal to 0.15 .

The final model is presented here:

Leverage $_{i t}$ or $\left(\frac{D}{A}\right)_{i t}$

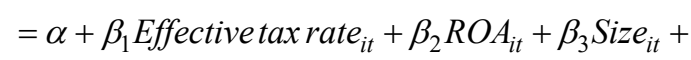

$+\beta_{4}\left(\frac{\text { Depreciation }_{\text {Sales }}}{\text { it }}+\beta_{5}\right.$ Tangibility $_{i t}+\beta_{6}$ Inflation $_{i t}$

$+\beta_{7}\left(\frac{N I}{\operatorname{Revenue~}}\right)_{i t}+\beta_{8}\left(\frac{E B I T}{E B T}\right)_{i t}+\xi_{i t}$

Table 6. Panel regression results for Brazilian companies, with fixed effects

\section{Variable}

Total debt/Total assets

$\begin{array}{ll} & 0.061^{\star \star} \\ & (0.37) \\ \text { Effective tax rate } & \text { p-value: } 0.109\end{array}$

ROA $-35.30^{* * * *}$

Size

Depreciation/Sales

$2.030^{* * * *}$

Tangibility

$-10.60^{* * * *}$

Inflation

$98.55^{*}$

(61.8) 


\begin{tabular}{|c|c|}
\hline Variable & Total debt/Total assets \\
\hline NI/Revenue & $\begin{array}{l}0.080^{\star * * *} \\
(0.02)\end{array}$ \\
\hline EBIT/EBT & $\begin{array}{l}-0.030 \\
(0.04)\end{array}$ \\
\hline Observations & 910 \\
\hline R-sq within & 0.15 \\
\hline
\end{tabular}

Levels of significance: $1 \%^{\star * * *}, 5 \%^{\star * *}, 10 \%^{\star *}, 15 \%^{*}$.

\section{India}

The sample consists of 905 firm-year observations for Indian companies from 2010 to 2014 (5 years). A panel regression with fixed effects is utilised. The coefficient of determination of the model (i.e. R-sq) is equal to 0.12 .

The final model is presented here:

Leverage $_{i t}$ or $\left(\frac{D}{A}\right)_{i t}$

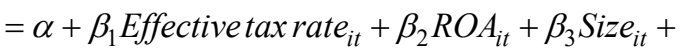

$+\beta_{4}\left(\frac{\text { Depreciation }_{\text {Sales }}}{\text { Sit }}+\beta_{5}\right.$ Profitability $_{i t}+\beta_{6}$ Inflation $_{i t}+$

$+\beta_{7} L I B O R_{i t}+\beta_{8}\left(\frac{E B I T}{E B T}\right)_{i t}+\xi_{i t}$

Table 7. Panel regression results for Indian companies, with fixed effects

\begin{tabular}{|c|c|}
\hline Variable & Total debt/Total assets \\
\hline Effective tax rate & $\begin{array}{l}-0.48^{\star \star} \\
(0.3) \\
\text { p-value: } 0.106\end{array}$ \\
\hline ROA & $\begin{array}{l}1.36^{* * * *} \\
(0.37)\end{array}$ \\
\hline Size & $\begin{array}{l}8.63^{\star * * *} \\
(2.77)\end{array}$ \\
\hline Depreciation/Sales & $\begin{array}{l}-2.01^{\star * * *} \\
(0.72)\end{array}$ \\
\hline Inflation & $\begin{array}{l}66.79^{* * * *} \\
(13.9)\end{array}$ \\
\hline Profitability & $\begin{array}{l}-4.53 \\
(3.61)\end{array}$ \\
\hline
\end{tabular}

\begin{tabular}{|c|c|}
\hline EBIT/EBT & $\begin{array}{l}0.04 \\
(0,04)\end{array}$ \\
\hline LIBOR & $\begin{array}{l}851 \cdot 2^{\star * * *} \\
(199,9)\end{array}$ \\
\hline Observations & 905 \\
\hline R-sq within & 0.12 \\
\hline
\end{tabular}

Levels of significance: $1 \%^{\star \star \star *}, 5 \%^{\star \star \star}, 10 \%^{\star *}, 15 \%^{\star}$.

\section{South Africa}

The sample includes 760 firm-year observations for South African companies from 2010 to 2014 (5 years). A panel regression with fixed effects is utilised. The coefficient of determination of the model (i.e. R-sq) is equal to 0.11 .

The final model looks like:

Leverage $_{i t}$ or $\left(\frac{D}{A}\right)_{i t}$

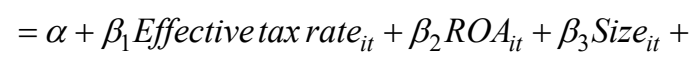

$+\beta_{4}\left(\frac{\text { Depreciation }_{\text {Sales }}}{\text { it }}+\beta_{5}\right.$ Tangibility $_{i t}+\beta_{6}$ Inflation $_{i t}+$

$+\beta_{7}\left(\frac{N I}{\text { Revenue }}\right)_{i t}+\beta_{8}\left(\frac{E B I T}{\text { Total Assets }}\right)_{i t}+\xi_{i t}$

Table 8. Panel regression results for South African companies, with fixed effects

\section{Variable Total debt/Total assets}

Effective tax rate (0.02)

p-value: 0.041

ROA

$-11.90^{* * * *}$

(4.12)

Size $7.61^{\star * * *}$

(2.07)

Depreciation/Sales

$26.7^{\star}$

(17.7)

$\begin{array}{ll} & 0.72^{\star * * *} \\ \text { Tangibility } & (0.2)\end{array}$

EBIT/Total assets

5.30

(4.6)

Observations 760

R-sq within $\quad 0.11$

Levels of significance: $1 \%^{\star * * *}, 5 \%^{\star * *}, 10 \%^{\star *}, 15 \%^{*}$. 


\section{China}

The sample includes 4000 firm-year observations for Chinese companies from 2010 to 2014 (5 years). A panel regression with fixed effects is utilised. The coefficient of determination of the model (i.e. R-sq) is equal to 0.07 .

The final model looks like:

$$
\begin{aligned}
& \text { Leverage }_{i t} \text { or }\left(\frac{D}{A}\right)_{i t} \\
& =\alpha+\beta_{1} \text { Effectivetax rate }_{i t}+\beta_{2} \text { ROA }_{i t}+\beta_{3} \text { Size }_{i t}+ \\
& +\beta_{4}\left(\frac{\text { Depreciation }_{\text {Sales }}}{\text { Sat }_{i t}}+\beta_{5} \text { LIBOR }_{i t}+\beta_{6} \text { Inflation }_{i t}+\right. \\
& +\beta_{7} \text { Growth }_{i t}+\xi_{i t}
\end{aligned}
$$

\begin{tabular}{|c|c|}
\hline Variable & Total debt/Total assets \\
\hline Effective tax rate & $\begin{array}{l}0.14^{\star * * *} \\
(0,04) \\
\text { p-value: } 0.002\end{array}$ \\
\hline $\mathrm{ROA}$ & $\begin{array}{l}-39 \cdot 62^{* * * *} \\
(7,39)\end{array}$ \\
\hline Depreciation/Sales & $\begin{array}{l}-1.680^{\star * * *} \\
(0,41)\end{array}$ \\
\hline Size & $\begin{array}{l}3.310^{* * * *} \\
(0,93)\end{array}$ \\
\hline LIBOR & $\begin{array}{l}206.79^{* * *} \\
(73,67)\end{array}$ \\
\hline Inflation & $\begin{array}{l}89.95^{\star * * *} \\
(18,57)\end{array}$ \\
\hline Growth & $\begin{array}{l}-7.23^{\star} \\
(4,9)\end{array}$ \\
\hline Observations & 4000 \\
\hline R-sq within & 0.07 \\
\hline
\end{tabular}

Table 9. Panel regression results for Chinese companies, with fixed effects

Levels of significance: $1 \%^{\star \star \star \star}, 5 \%^{\star \star \star}, 10 \%^{\star \star}, 15 \%^{\star}$.

\section{Conclusion}

In this work, I investigated the impact of taxation on the capital structure of companies in BRICS countries. During this research, regression analyses were conducted for the companies of each of BRICS countries. These regression analyses showed that for all countries except Russia, the most suitable regression model is the fixed effects method, but for Russia the most appropriate model is the random effects method. The obtained results indicate that effective tax rate is an important capital structure determinant, and it is significant across all countries.

Effective tax rate has an ambiguous effect on the leverage of companies, that is, it is either positive or negative. In countries such as Russia, India, and South Africa, effective tax rate has a significant negative relationship with financial leverage. This fact contradicts most existing financial literature, where effective tax rate has a positive relationship with the capital structure. The negative impact on leverage of the effective tax rate can be explained through the regulated expenses for income tax (as seen in Russia). Also, in the paper of I. Ivashkovskaya, M. Solntseva (2009) [41], the authors identified a negative relationship between tax and capital structure. They explained this result as follows: the higher the tax savings caused by payment of debt interest, the lower the level of leverage. However, the effective tax rate's impact on capital structure of Brazil and China is in line with most researches in that there is a positive relationship between effective tax rate and capital structure.

The results of the present study indicate that the return on assets (ROA) value is negatively related to leverage in Brazil, South Africa, Russia and China. This result corresponds to the pecking order theory, which states that companies should prefer internal financing. However, ROA was found to be positively related to capital structure in India, which is a result supported by the tradeoff theory.

Moreover, the size of the firm was found to have a positive relationship with leverage in all countries except Russia, where this determinant is insignificant. This result corresponds to the research by S. Byoun (2008) [40], which indicates that large companies have lower agency costs, easier access to credit markets and less volatile cash flows.

Further analysis of the determinant designated as 'depreciation/sales' reveals that it is positively related [23] to leverage in Brazil and South Africa. This coincides with the results of M. Faccio, J. Xu (2015) and I. Ivashkovskaya, M. Solntseva (2007) [38], whereas an opposite result was obtained for India and China.

Finally, the tangibility variable was seen to negatively relate to capital structure in Brazil, but positively so in South Africa, and inflation has a positive sign and is significant in Brazil, India and China. There are some other significant determinants, but they are unique for each country. According to these results it may be concluded that these countries' samples cannot be combined or analysed as a unified dataset, because they are too different and demonstrate too much complex variation.

In accordance with the results obtained during the analyses, the following conclusions may be stated regarding the hypotheses articulated earlier:

H1: The effective tax rate positively relates to company leverage in BRICS countries.

This hypothesis has been rejected for Russia, India and South Africa, but proven for Brazil and China. 
H2: The return on assets negatively relates to company leverage in BRICS countries.

This hypothesis has been proven for Russia, Brazil, South Africa and China, but rejected for India.

H3: The inflation rate positively relates to the company leverage in BRICS countries.

This hypothesis has been rejected for Russia and South Africa, but proven for Brazil, India and China.

\section{References}

1. Modigliani F., Miller M. H. The cost of capital, corporation finance and the theory of investment // The American economic review. - 1958. - T. 48. - №. 3. - C. 261-297.

2. Modigliani F., Miller M. H. Corporate income taxes and the cost of capital: a correction //The American economic review. - 1963. - T. 53. - №. 3. - C. 433443.

3. Graham, John R. Taxes and corporate finance: A review // Review of Financial Studies. - 2003. - T. 16. - №1. - C. 1093-1094.

4. Dhaliwal D., Trezevant R., Wang S.. Taxes, Investment-Related Tax Shields and Capital Structure// Journal of the American Taxation Association. - 1992. - T. 14. -№1. - C. 1-21.

5. MacKIE-MASON J. K. Do taxes affect corporate financing decisions? //The journal of finance. - 1990. - T. 45. - №. 5. - C. 1471-1493.

6. Graham J. R., Harvey C. R. The theory and practice of corporate finance: Evidence from the field //Journal of financial economics. - 2001. - T. 60. - №. 2. - C. 187-243.

7. Givoly D. et al. Taxes and capital structure: Evidence from firms' response to the Tax Reform Act of 1986 // Review of Financial Studies. - 1992. - T. 5. - №. 2. C. 331-355.

8. Fan J. P. H. et al. An international comparison of capital structure and debt maturity choices. - 2010.

9. Rajan R. G., Zingales L. What do we know about capital structure? Some evidence from international data //The journal of Finance. - 1995. - T. 50. - №. 5. - C. 1421-1460.

10. Barakat M., Rao R. P. The role of taxes in capital structure: evidence from taxed and non-taxed Arab economies //Available at SSRN 2026751. - 2012.

11. Longstaff F. A., Strebulaev I. A. Corporate taxes and capital structure: A long-term historical perspective. - National Bureau of Economic Research, 2014. - №. w20372.
12. Bas T., Muradoglu G., Phylaktis K. Determinants of capital structure in developing countries //Research Paper Series. Cass Business School, London, UK. 2009.

13. Hemmelgarn T., Teichmann D. Tax reforms and the Capital structure of banks //International Tax and Public Finance. - 2014. - T. 21. - №. 4. - C. 645-693.

14. De Socio A., Nigro V. Does corporate taxation affect cross-country firm leverage? //Bank of Italy Temi di Discussione (Working Paper) No. - 2012. - T. 889.

15. Nyamita M. O., Garbharran H. L., Dorasamy N. Factors influencing debt financing decisions of corporations-theoretical and empirical literature review. - 2014.

16. Barrios S. et al. International taxation and multinational firm location decisions. - 2008.

17. Gordon R. H. et al. Taxation and corporate use of debt: Implications for tax policy //National Tax Journal. - 2010. - T. 63. - №. 1. - C. 151-174.

18. Chen Y., Gong N. The impact of taxes on firm value and the trade-off theory of capital structure // European Financial Management Association Annual Conference. Barcelona, Spain. - 2012.

19. Hartmann-Wendels T., Stein I., Stöter A. Tax incentives and capital structure choice: Evidence from Germany //Available at SSRN 2140896. - 2012.

20. Kim W., Lee H. J. Debt and Taxes: Evidence from Foreign versus Domestic Subsidiaries in an Emerging Market //Asia-Pacific Journal of Financial Studies. 2015. - T. 44. - №. 2. - C. 246-280.

21. Dwenger N., Steiner V. Financial leverage and corporate taxation: Evidence from German corporate tax return data //International tax and public finance. - 2014. - T. 21. - №. 1. - C. 1-28.

22. Miniaci R., Parisi M. L., Panteghini P. M. Debt shifting in Europe //International Tax and Public Finance. - 2014. - T. 21. - №. 3. - C. 397-435.

23. Faccio M., Xu J. Taxes and capital structure //Journal of Financial and Quantitative Analysis. - 2015. - T. 50. - №. 03. - C. 277-300.

24. DeAngelo H., Masulis R. W. Optimal capital structure under corporate and personal taxation //Journal of financial economics. - 1980. - T. 8. - №. 1. - C. 3-29.

25. Givoly D., Hayn C. The valuation of the deferred tax liability: Evidence from the stock market // Accounting Review. - 1992. - C. 394-410.

26. Scholes M. S., Wilson G. P., Wolfson M. A. Tax planning, regulatory capital planning, and financial reporting strategy for commercial banks //Review of financial Studies. - 1990. - T. 3. - №. 4. - C. 625-650. 
27. Trezevant R. Debt Financing and Tax Status: Tests of the substitution effect and the tax exhaustion hypothesis using firms' responses to the economic recovery tax act of 1981// Journal of Finance. - 1992. - T.4. - №47. - C. 1557-1568.

28. Schulman C. T. et al. Effects of tax integration and capital gains tax on corporate leverage //National Tax Journal. - 1996. - C. 31-54.

29. Pauline M. Shum, 1996, The Canadian Journal of Economics / Revue canadienne d'Economique Vol. 29, No.3, pp. 556-572

30. Cloyd C. B., Limberg S. T., Robinson J. R. The impact of federal taxes on the use of debt by closely held corporations //National Tax Journal. - 1997. - C. 261-277.

31. Gordon R. H., Lee Y. Do taxes affect corporate debt policy? Evidence from US corporate tax return data //Journal of Public Economics. - 2001. - T. 82. - №. 2. - C. 195-224.

32. Ayers B. C., Cloyd C. B., Robinson J. R. The influence of income taxes on the use of inside and outside debt by small businesses //National Tax Journal. - 2001. C. 27-55.

33. Buettner T. et al. Taxation and capital structure choice-evidence from a panel of German multinationals //Economics Letters. - 2009. - T. 105. - №. 3. - C. 309-311.

34. Dhaliwal D. S., Erickson M. M., Krull L. K. Incremental financing decisions and time-series variation in personal taxes on equity income // Journal of the American Taxation Association. 2007. - T. 29. - №. 1. - C. 1-26.

35. Voeller D., Overesch M. The Impact of Personal and Corporate Taxation on Capital Structure Choices. ZEW Discussion Papers, 2008. - №. 08-020.

36. Klapper L. F., Tzioumis K. Taxation and Capital Structure: evidence from a transition economy // World Bank Policy Research Working Paper Series, Vol. - 2008.
37. Jong A., Kabir R., Nguyen T. Capital structure around the world: The roles of firm- and country-specific determinants// Journal of Banking \& Finance. - 2008. - T.32. - №9. - C. 1954-1969.

38. Ivashkovskaya I. V., Solntseva M. S. The capital structure of Russian companies: testing trade-off theory versus pecking order theory //Корпоративные финансы. - 2007. - №. 2. - С. 17-31.

39. Kayo E. K., Kimura H. Hierarchical determinants of capital structure //Journal of Banking \& Finance. 2011. - T. 35. - №. 2. - C. 358-371.

40. Byoun S. How and when do firms adjust their capital structures toward targets? //The Journal of Finance. 2008. - T. 63. - №. 6. - C. 3069-3096.

41. Ivashkovskaya I., Solntseva M. Capital Structure Choice in BRIC: Do Russian, Brazilian, and Chinese Firms Follow Pecking Order or Trade-Off Logic of Financing //Business Strategies and Technological Innovations for Sustainable Development/Global Business and Technology Association Eleventh International Conference Readings Book, Edited by N. Delener, L. Fuxman, FV Lu, A. Putnova, LE Rivera-Solis. NY. - 2009. - C. 572-580

42. Baltacı, N., Ayaydın, H. Firm, Country and Macroeconomic Determinants of Capital Structure: Evidence from Turkish Banking Sector// EMAJ: Emerging Markets Journal. - 2014. - T. 3. - №3. C.47-58.

43. Jõeveer K. Firm, country and macroeconomic determinants of capital structure: Evidence from transition economies //Journal of Comparative Economics. - 2013. - T. 41. - №. 1. - C. 294-308.

44. Huang G., Song F. The determinants of capital structure: Evidence from China// China Economic Review, Elsevier. - 2006. - T.17. - №1. - C.14-36

45. Brierly P., Bunn P. The determination of UK Corporate Capital Gearing// Bank of England, Quarterly Bulletin. - 2005. - T.45. - №3. - C. 356. 